\title{
Australian Foreign Politics on Indonesia: A Case Study of West Irian 1949-1962
}

\author{
Budi Purnomo \\ Department of History Education, Faculty of Education and Teacher Training Program, Uni versitas Jambi, \\ Indonesia \\ budipurnomo@unja.ac.id
}

\begin{abstract}
This paper examines Australian foreign policy among Indonesian, especially on the West Irian case in 1949-1962. The bilateral relationship between Indonesia-Australia from 1949-1962 always goes through up and down "Roller Coaster." The relationship between both countries is not structured. No mechanism is arranged, so it depends on the political development and the situations, especially defense and political problems. Indonesia claimed that West Irian is supposed to be a menace for Australian security. Australia put West Irian as a Vital Interest concept. In the cabinet session on January 11, 1962, Australia do "Volte Face" and confess that the vital interest concept is not invalid anymore because there is no menace evidence for Australia or region Australia interest.
\end{abstract}

Keywords foreign policy; Indonesia-Australia; bilateral relations

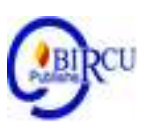

\section{Introduction}

The bilateral relationships between Australia and Indonesia have an interesting one to observe, because it has its own uniqueness. It is unique, because the relationship between the two countries is like a "Roller Coaster", rising slowly after reaching the peak, it drops dramatically. The relationship between the two countries, which was officially established after Indonesian independence, always had ups and downs. The rise of issues that mostly involve the image of the two countries can create a misconception, which in turn has an impact on the bilateral relations between the two parties. Although both countries have the same interests, the differences between them are wrong in the fragility of relationships between Indonesia and Australia. This ambivalent perception is also influenced by the limited structure of bilateral relations between the two countries, so that it often leads to misunderstandings in interpreting the foreign policy steps of each country (Hilman Adil 1993). The limitations of the structure of the bilateral relationship are partly due to the limited sources of information that is inaccurate.

The ebb and flow of Australia-Indonesia relations are because the two countries are in a strategic position. It cannot be denied that Australia has an excessive fear of threats from Indonesia. As emphasized by Paul Keating in his speech entitled "Our Common Interests" in front of an overseas forum in Jakarta, Indonesia is at the top of Australia's priorities, because Indonesia is the closest neighbor that plays a major role in this region, where Australia's future lies (Hilman Adl 1993). Indonesia is also a very important country and is considered to be the key to the stability of this region (Australian Region) (Sumardi 1985).

The gap in the Australia-Indonesia relationship cannot be separated from the role of domestic actors in its formulation and implementation. Domestic actors include executives, political parties, individuals or communities, parliaments, groups, interests, the 
press, and the mass media. It is these elements that characterize the creation of continuity in Australian foreign policy, particularly regarding the operating style that is different from the personality of the people in power at the time. For example, the AustraliaIndonesia relationship during the Labor Party government (1941-1949) was strongly supported by the personal political convictions of their leaders (Chauvel, 1992).

Like day and night, Australia-Indonesia relations had reached a very sweet period in the period 1946-1949 when the workers' party government came to power. Especially during the reign of Chifley and Secretary of State Dr. H.V. Evatt, who succeeded in delivering Indonesia's independence, received international recognition at the end of 1949. This tidal wave could not be enjoyed for too long. The Australia-Indonesia relationship that was developed from 1947-1949 was hit by a storm when in the early 1950s Indonesia claimed West Irian which was proposed at the KMB (Round Table Conference). Indonesia's claim to West Irian has come under fire from the coalition government of the Liberal-Country Party which won the 1949 elections. Since then the bilateral relations between Australia and Indonesia during the 1950s and early 1960s (more than a decade) were colored by issues regarding West Irian. The sweet history that was built by the two countries did not last forever. This article seeks to see how Australian foreign policy from various sides, especially in the West Irian case in 1949-1962.

\section{Review of Literatures}

\subsection{Post-World War Australia Foreign Politics II}

After World War II, almost all over the world there were major changes in politics, where several countries in Europe became countries controlled by the communist party. Meanwhile, both in Asia and Africa, nationalism developed which eventually gained its independence. The change in the face of world politics has an effect on Australian foreign policy. This is evidenced by several events that took place in the period 1940-1970.

Back on the events of 1941-1942 also created defining points in Australian foreign policy history. The fall of Singapore, Malaya, and the Dutch East Indies at the hands of Japan and the sinking of the British warships Prince of Wales and Repulse made Australia aware of the threat posed by Japan and foreign nations and demonstrated Britain's inability to ensure Australia's security.

The chaos of Australia's foreign policy problems after World War II forced a break with the previously adopted policies. For the first time during the reign of Robert Bondon Menzies from the Liberal Party between 1939-1949. Then continued by Foreign Minister H.V. Evatt from the Labor Party during the Courtin and Chiefly reigns between 1941-1949 and the Liberal-Country Party coalition government led by R.G. Menziez from 1949-1966. They then provide a new dimension to Australia's post-World War II foreign policy. And 1939 is seen as a significant milestone in a major shift in Australia's foreign policy-making process. Because in the previous 50 years, Australia did not feel free to determine its foreign policy because of its ties to Britain.

In the 1950s and early 1960s, when Prime Minister Menzies came to power, Australian foreign policy was primarily determined by small groups or individual elements (P.G Edwards 1987). The personal part had always played an essential role in the history 
of Australian foreign policy when H.V Evatt was Foreign Minister in the Curtin and Chiefly government (1941-1949) and when R.G Menzies was Prime Minister of the coalition of Liberal and Country Parties (1949-1966). Consequently, the government's thoughts and policies depend on which party is currently in power.

The end of World War II has also brought about fundamental changes in Australian foreign policy. Australia has gained valuable experience, especially its views on Southeast Asia, where nationalism began to grow to dispel colonialism. The new perception towards Southeast Asia prompted Australia to pay attention to Southeast Asia as its close neighbor and its strategic importance to Australia's internal security, as stated by Foreign Minister H.V Evatt about the Southeast Asia region's importance pacific region for Australia. Likewise, Minister for Foreign Affairs Sir Percy Spender from the Liberal-Country Party coalition (1949-1951) saw Australia's strategic geographical situation in the Pacific region and close to the Southeast Asia region.

Australia's attention is getting bigger, especially with the growth of new countries in the region under the pretext of establishing cooperation. Especially in stemming the influence of communism in Southeast Asia. After 1949 Australia also tried to develop relationships with countries around the Pacific Ocean in the political, economic and social, and cultural fields (J.P.SJ. Schlegel 1984). As the United States' influence and strength grew in the Pacific, Australia relied on American power for its security.

In 1950, Australia also participated in forming the Colombo Plan, a plan to support developing countries in South and Southeast Asia. Since 1972, Australia has found an independent spirit in its foreign policy by renouncing its ties to or dependence on Britain and the United States.

\subsection{Australia - Indonesia Relations, 1945-1949}

The history of relations between Indonesia and Australia is off to a good start. The warmth of their relationship indicated by the evidence that Australia supports and helps the Indonesian people's struggle to recognize sovereignty in the period 1945-1949. In the four years (1945-1949), Australia and Indonesia relations when the workers' party came to power also ran quite well. The issue of West Irian at that time had not yet emerged. Indeed, at first, Australia's official attention to developments taking place in Indonesia was minimal. Despite the end of 1945, the negotiations between Indonesia and the commander of the allied forces in the Dutch East Indies (AFNEI) were followed closely. There are two reasons: first, there were a separation of the Australian military's role or troops from being directly involved in the fighting in Sumatra and Java. As a result, Australia's policy will not affect the policy of allied forces in Indonesia. Second, in Canberra, there is a strong feeling that Australia should try to avoid any involvement in any colonial problem in Indonesia. Prime minister J.B. Chiefley in front of parliament on August 29, 1945, said that the general principles implemented by the government regarding civil matters (except in Papua and Australia's dependent areas), the government would try to refrain from being responsible for civil cases and the re-occupation of a site (Hilman Adil, 1993). Foreign Minister H.V. Evett said that the Dutch East Indies should remain a shield for northern Australia's defense. 
Therefore, the Netherlands should not give up its sovereignty (H.V. Evett, 1945). The Indonesian archipelago that stretches along northern Australia will form a defense system in the north part and economic considerations. Therefore, the Dutch government's continuity is a prerequisite for maintaining a politically stable region, which will benefit Australian trade.

The period 1946-1949 shows a unique thing. If the relationship between the two countries experienced an "ebb and flow," then in 1946-1949, there was a tidal wave. There was a change in Australia's attitude from siding with the Dutch to turning sympathetic to the Indonesian people's struggle. Australia's support is inseparable from the role or pressure of the waterside workers union. They did a boycott of Dutch ships going to Indonesia. Beddie said that Australia's policy of neutrality had changed due to political pressures exerted by WWF. If there is no pressure, the workers' party government will not easily support Indonesia (Hilman Adil, 1993).

Australian sympathy was also evidenced by Australia's participation in the ceasefire negotiations between Indonesia and the Netherlands. Where Australia represents Indonesia, it sits on the good services committee or the three-country committee. This commission was later upgraded to become the United Nations Commission on Indonesia (UNCI). Australian sympathy was evidenced by Australia's participation in the ceasefire negotiations between Indonesia and the Netherlands. Where Australia represents Indonesia, it sits on the right services committee or the three-country committee. This commission was upgraded to become the United Nations Commission on Indonesia (UNCI).

George (1980) noted that when Indonesia struggled to defend its independence, Australia's attitude felt significant moral support. In two military aggressions against Indonesia, Australia always criticized the Netherlands. The first Dutch Military Aggression, Australia, advised Indonesia to ask the U.N. Secretary General's direct assistance with Indian mediation. Australia, the second Dutch military aggression, asked the U.N. Security Council to stop the Dutch attack immediately. Even N.J.O. is increasingly on behalf of Australia, saying:

"The action of the Netherlands cannot be condone. To ignore is to condone, to delay is to condone. The council Should immediately consider measures it can take within its authority to bring peace to Indonesia" (M. George 1980).

Australia - Indonesia relations reached a delightful period when Australia succeeded in bringing Indonesia's independence to international recognition at the end of 1949. Thus, Australia thought Australia was the sponsor of Indonesia's independence and membership in the United Nations. And Indonesia, the result of the KMB was almost the creation itself (Australia) and Foreign Minister H.V. Evatt as Indonesian independence midwife.

In response to this issue, J.A.C. Mackie, an expert on Australia-Indonesia relations, said that the workers' party government's tendency to support Indonesia from 1945 to 1949 was mainly his concern if the Dutch were proven unable to maintain their colonial power (except by applying continuous pressure). The Dutch's inability as Australia's shield against attacks from mainland Asia (Japan) in 1942 is still not forgotten. 


\section{Discussion}

\subsection{Australian Perspective on the West Irian Problem 1949-1957}

The geographic proximity of the two countries directly adjacent does not guarantee the relationship between the two runs in harmony continues. Australia - Indonesia bilateral relations during the 1950s to 1960s (more than a decade) experienced a decline. The ebb and flow occurred because it was triggered by West Irian's issue that had emerged since the $1949 \mathrm{KMB}$. West Irian for Indonesia was a national demand based on the preamble to the 1945 Constitution, which stated: to form the Indonesian nation and Indonesia's blood (Nugroho Notosusanto 1984). Suppose the workers 'party under Chiefley's previous administration has helped and fully supported Indonesia. In that case, Indonesia's claim to West Irian backfires for the workers' government, and finally had to accept his defeat in the 1949 election.

R.G. government policy Menzies from the coalition of liberal-country party parties that won the 1949 election against Indonesia was in stark contrast, coinciding with the emergence of the West Irian issue. Menzies placed the concept of West Irian's "vital interests" for Australia's defense as a crucial element in Indonesia's policy. An area that is very sensitive to Australia from the three regions (Malaya, Indonesia, and New Guinea) that have received Australia's attention is West Irian (Gordon Greenwood and Norman Harper (ed), no year). The strategic assumption is that West Irian is Australia's last ring of defense against aggression. For this reason, West Irian must be under the rule of a friendly state that can prove its stability. The Netherlands was seen as more worthy than Indonesia, and Indonesia's claim to West Irian was seen as a step towards strategic transformation. It would disrupt the balance of forces in Southeast Asia and as a weakness for Australia's defense.

Post World War II, Irian also has significance for Australia after the United States abolished the astronauts (200 miles north of Irian and scattered among the Admiralty Islands) as an integral part of its pacific defense perimeter (Kyle Tennant, Evatt 1970 and Hilman Adil 1993). According to Alfian Muthalib (1985), the vital meaning of Irian is because Irian as a whole is considered the defense perimeter of Australia. Australia's reaction stems from the role of Papua New Guinea in Australian history. The territory of New Guinea for Australia is considered a defense barrier (Defense Barrier) and the region's political and economic development. If the Dutch control West Irian, there will be better cooperation with East Irian.

Arthur Calwell from the opposition labor party warned the Australian government that if Indonesia's claim to West Irian were allowed to do so, Indonesia would also do the same to East Timor, Papua New Guinea, and the territory of North Australia (John Molony 1987). Foreign Minister Percy Spender made a statement on 2 March 1950 that Irian was an essential link in Australia's chain of connection (Alan Watt 1967). And the New Guinea region is the primary key to Australia's defense, and Australia cannot stand by the situation that could threaten Australia from an island close to Australia.

The outbreak of the Korean War on June 25, 1950, and the emergence of the ChinaSoviet Union's mutual assistance and friendship agreement on February 14, 1950, 
demonstrated America's inability to maintain security in the Pacific. So America needs to widen its defensive line, which includes Australia and New Zealand. In this connection, Irian has strategic meaning for Australia's defense. Moreover, the Indonesian government's policy (1949), which did not want to be bound by the American defense line built to face China, which was initially considered a central element, turned into an open southern side. For that, Irian is a choice. It was difficult for Australia to accept Indonesia's "Don't Want to Bound" attitude (Mohammad Hatta 1953). Because there are concerns for Australia and Western countries, Indonesia's neutral stance will make Indonesia vulnerable to communist influence.

On June 8, 1950, Foreign Minister Percy Spender repeated his statement that Australia's stance on West Irian's issue did not recognize Indonesia's demands for West Irian. Responding to this statement, President Soekarno, on June 11, 1950, in a speech in Jakarta, said that Indonesia must have a unitary state, which includes West Irian. Without West Irian, Indonesia's independence would not be complete. In Melbourne Age, the leading daily newspaper, June 13, 1950, stated that Indonesia's claim is considered to have no factual basis if it is related to racial origin, geographic conditions, and ethnicity (Hilman Adil 1973).

Australia's worrying attitude towards Indonesia's claim to West Irian and Indonesia's accusation of being expansionist did not get a strong response from Indonesia due to limited contact between the two countries. The formulation of Indonesia's foreign policy towards Australia is unclear. Indonesia did not think there was a need to respond to Australia in the West Irian issue because for Indonesia, the parties directly involved were the Netherlands and Indonesia. Indonesia then submitted the West Irian problem to the UN forum in 1954, and Indonesia continued to fight for the West Irian issue to be included in the agenda of the UN general assembly session.

\subsection{Australian "Two Faced" Politics and the Final Completion of West Irian 1958- 1962}

Australia-Indonesia relations from 1958 - 1962 were still hit by a wave of letters, although there were signs of a ripple of ups and downs. In other words, the two countries both recognize the importance of fostering good relations between the two countries. This period began with neighborly politics. One proof of intensive good relations is mutual visits between high-ranking officials of the two countries. For example, from early 1959 to April 1961, the Australian government attempted to improve its ties by inviting Foreign Minister Subandrio to visit Australia (February 1959) the PM Menzies visit to Jakarta (October 1961). The goal is to gain a better mutual understanding between the two countries.

In the 1959 visit of Subandrio to Australia, Subandrio said that the geographical location required close mutual understanding in all fields. Indonesia rather than Netherland, which received Australian support. Arthur Calwell of the Labor Party stated that Australia's attitude had weakened the Netherlands' status in West Irian so that the taking of the territory was inevitable. If this happened on the commemoration of the communist commemoration, it became stronger (Harian Merdeka, 26 1957). 
Behind this good neighborly politics, it turns out that there are efforts to prepare the Australian military to face the possibility of Indonesian intervention in West Irian. In other words, the Australian side wanted to establish good relations with Indonesia, but on the other hand, the pro-Dutch military cooperated with the Dutch in the defense sector. After the cooperation agreement between Australia and Netherland was signed, Indonesia and Australia paid attention to their respective interests to resolve the problem. Finally, it brings a new awareness that the West Irian problem must be a significant concern in the bilateral relations between the two countries. The Jakarta-Canberra communication flow remains open to achieve a better mutual understanding.

Indonesia is also trying to build good relations with countries by sending goodwill missions. This mission was also carried out to Australia to explain Burhanuddin's policy on the West Irian issue and Indonesia's desire to normalize its relations with western countries. This mission was led by Foreign Minister Mohammad Rum and succeeded in creating a better understanding of Indonesia's steps to resolve this problem with the Netherlands peacefully. Australia has not committed to supporting Indonesia's demands.

In the early 1960s, West Irian's issue was heated again as a result of the Dutch plan to accelerate West Irian under one self-government and the increasing danger of the Indonesian-Dutch military conflict. In May 1960, the Dutch sent the aircraft carrier Karel Doorman to West Irian, which was immediately considered an offensive threat to Indonesia. To deal with possible Dutch intervention, Indonesia sought military assistance. In 1960 the construction of the modern military began. This situation has awakened the western world, and in time Indonesia will use its military power.

This urgent situation eventually changed the attitude or policy of the United States, which was then led by John F.Kennedy, from passive neutrality policy to active mediation policy in settling West Irian. On the American initiative, Dutch-Indonesian negotiations were held, but they came to a dead-end, and Indonesia continued to increase its pressure towards war. On 24 February 1962, President Soekarno announced to the Indonesian people to prepare a general mobilization for West Irian liberation.

Then on February 26th, 1962, the US refused to guarantee the Dutch in an attack from Indonesia. Meanwhile, at the Cabinet meeting on January 11th, 1962, Australia conducted a volte-face (totally changed course) of its foreign policy on the West Irian issue. In a sense, Australia can accept Indonesia in West Irian, and Australia recognizes that the concept of "vital interest" is no longer valid (Hilman Adil 1973). The reason, according to Sir Garfield Barwick, is that he sees no evidence of a threat to Australia or any of Australia's regional interests. On March 14, 1962, Dutch-Indonesian negotiations were held under UN supervision. The Indonesian delegation was led by Adam Malik and the Dutch by Dr. J.H. Van Royen. On March 26, 1962, Indonesia resigned from the forum, but on July 13, 1962, the two sides reopened talks, which finally reached an agreement on West Irian's settlement.

Nonetheless, efforts to improve strong bilateral relations are always underway. They also agreed to set aside issues that could lead to conflict. Indonesia and Australia view that the two countries can become partners to work together in the political, economic, socio- 
cultural, and defense-security fields. To achieve this goal, they feel the need for a sense of trust in each party that they are partners with each other.

\section{Conclusion}

Australia-Indonesia bilateral relations 1949-1962, in 13 years, have always experienced changes. The ebb and flow of relations between the two countries depend on certain developments or political situations, both in Australia and Indonesia and in an international framework. The relationship between the two parties is not structured, and there is no governing mechanism. Politics and defense are still the main focus. Besides, domestic actors (executives, political parties, individuals or communities, parliaments, interest groups, the press, and the mass media) always characterize Australian foreign policy.

Australia's foreign policy towards Indonesia after World War II during the Labor Party government shows a dilemma. On the one hand, Indonesia is a threat to Australia's security (e.g., confrontation with Malaysia, Indonesia's claim to West Irian as one proof). The government policies of the coalition of liberal-country party parties towards Indonesia and the West Irian problem's emergence are in stark contrast. Australia places the concept of vital importance on the West Irian problem. A view of the importance of strategic importance of West Irian to Australian security precludes any desire to reach an agreement with Indonesia on the issue. Particularly concerning the security aspect, it severely limits the space for Australia to move further.

\section{References}

Anonim, 1957. Harian Merdeka, 26 Februari 1957. PT. Merdeka Press, Jakarta.

Adil, H. 1973, Australia's Relation With Indonesia 1945-1962. Disertasi Untuk Meraih Doktor di Universitas Leiden, Belanda.

Adil, H. 1993. Hubungan Australia dengan Indonesia 1945-1962. Djambatan, Jakarta.

Chauvel, Richard H. 1992. Budaya dan Politik Australia. Jakarta: Yayasan Obor Indonesia.

Edwards, P.G. 1987. Foregn Policies dalam Australia: A. Historical Dictionary, Syne \& Weldom Associates, NSW: Farfax.

Evatt, H.V. 1945. Foregn Policy of Australia, Angus and Robertson, Sidney.

George, M. 1980. Australia and the Indonesian Revolution. Melbourne University Press, Cariton, Victoris.

Greenwood, Gordon and Harper, Norman (ed), t.t Australia in World Affairs 1961-1965, FW, FW Chesirem Publishing Pty Ltd. Melbourne.

Hatta, H. 1953. Dsara Politik Luar Negeri Republik Indonesia, Tintamas, Jakarta.

Molony, John. 1987. The Penguin Biscentinial History of Australia, Viking Pengujin Books LTD. Victoria.

Muthalib, A. 1985. Indonesia dan pasifik Barat Daya: Australia, Selandia Baru dan Papua New Guinea, Analisa No.8. Jakarta.

Notosusanto, N. 1984. Sejarah Nasional Indonesia 6, Balai Pustaka, Jakarta. 
Schlegel, J.P.S.J. 1984. Patterns of Diplomacy: Canada and Australia in The Third World, the Australian Journal of Politiecs and History.

Sumardi, 1985. Politik Luar Negeri Australia di bawah Partai Buruh, Grafindo Utama, Jakarta.

Tennant, K. 1970. Evatt, Politics and Justice, Angus and Robertson, Sydney.

Watt, A. 1967. The Evalution of Australian Foreign Policy 1938-1965, Cambridge University Press, London. 